\title{
CONCEPTUAL ASPECTS AND THE MOST USED PRACTICES IN OBTAINING THE RELIABILITY OF ENTITY VALUE ESTIMATION
}

\author{
Iulita BIRCA ${ }^{1}$, Scientific Researcher, \\ National Institute for Economic Research, Republic of Moldova \\ PhD Student USV „Stefan cel Mare”, Suceava, Romania \\ Mariana Rodica TIRLEA ${ }^{2}$, PhD, Associate Professor, \\ „Dimitrie Cantemir" Christian University, Bucharest, Romania \\ Victoria GANEA ${ }^{3}$, Professor, Habilitation in economics \\ State University of Moldova \\ Olga BUZU ${ }^{4}$, Habilitation in economics, Associate Professor, \\ Technical University of Moldova
}

DOI: https://doi.org/10.36004/nier.es.2021.1-02

JEL Classification: E32, F23, F32, F60, F65, M2, P19, P42

CZU: 657.922

\section{ABSTRACT}

Estimating the entity value is topical and of particular interest to managers and business owners, who in turn hope that through the evaluation they will obtain parallel and new possibilities for the business remediation. In this context, managers seek the support of qualified assessors, who will conduct a thorough analysis of the entity's state at a given date, will apply the most effective evaluation methods. In this paper we proposed to investigate and analyze the theoretical aspects of the entity value estimation (EVE), rendered in the opinion of the well-informed researchers and in the light of the evaluation standards. As a result, we note that the criteria of evaluations have been supplemented with the following criterion: by type of activity of the economic entity. We estimate the evaluation methods in order to identify the most accepted and effective method for this important process to the entity. For the practical aspect of the investigation, we focused on the method of comparison in the market valuation of the enterprise, in order to establish the statistical indicators consisting of the calculation of the median and the arithmetic mean. Based on the calculations made in the practical part, we have found that an economic entity can change its own value, in particular, by the way its values are profitable. In estimating the value of the entity, a decision-making function is attributed to the rests with the assessor, in particular with regard to the methods selected and applied professionally by the entity, in compliance with professional valuation standards and current regulations, as the fair estimation of the entity's value leads to a secure future and a guaranteed success.

Keywords: entity, value, valuation methods, valuation standards, evaluator, estimation, median, arithmetic mean.

Estimarea valorii entităţii este de actualitate și prezintă un interes deosebit pentru managerii și proprietarii unei afaceri, care, la rândul lor, speră ca prin intermediul evaluării să obțină paralel și noi posibilități de remediere a businessului. În acest context, managerii apelează la sprijinul evaluatorilor calificați, care vor desfășura o analiză profundă a stării entității la o anumită dată, vor aplica cele mai eficiente metode de evaluare. În această lucrare ne-am propus să cercetăm și să analizăm aspectele teoretice cu privire la estimarea valorii entităţii (EVE), redate în opinia cercetătorilor notorii și prin prisma standardelor de evaluare. Drept rezultat, menționăm că a fost completată schema criterială a evaluărilor cu următorul criteriu: după tipul de activitate al entităţii economice. Descriem metodele de evaluare cu scopul de a identifica pe cea mai acceptată și eficientă metodă pentru acest proces semnificativ pentru entitate. Pentru aspectul practic al investigației ne-am axat pe

\footnotetext{
${ }^{1}$ ID ORCID 0000-0002-3910-8022

${ }^{2}$ ID ORCID 0000-0002-0665-5839 e-mail: rodicatirlea10@yahoo.ro

${ }^{3}$ ID ORCID 0000-0002-6788-1856 e-mail: ganea.victoria@gmail.com

${ }^{4}$ ID ORCID 0000-0002-6702-466X $\bowtie$ e-mail: olbuzu@yahoo.com
} 
metoda comparaţiei în evaluarea de piaţă a întreprinderii, pentru a stabili indicatorii statistici care constau în calculul medianei și a mediei aritmetice. În baza calculelor efectuate în partea practică, am constatat că o entitate economică își poate schimba propria valoare, în special, prin modul de rentabilizare a valorilor sale. În procesul de estimare a valorii entităţii, o funcție decizională revine evaluatorului, în special în ceea ce privește metodele selectate și aplicate în mod profesional de către acesta, prin respectarea standardelor profesionale de evaluare și a reglementărilor actuale, deoarece estimarea justă a valorii entității conduce la un viitor sigur și la succes garantat.

Cuvinte-cheie: entitate, valoare, metode de evaluare, standarde de evaluare, evaluator, estimare, mediană, media aritmetică.

Оценка стоимости предприятия представляет особую актуальность и интерес для менеджеров и владельцев бизнеса, которые, в свою очередь, ожидают, что посредством оценки параллельно получат новые возможности для налаживания бизнеса. В этом контексте менеджеры пользуются поддержкой квалифицированных оценщиков, которые проводят углубленный анализ состояния предприятия на заданную дату и примененяют наиболее эффективные методы оценки. В данной статье мы стремились исследовать и проанализировать теоретические аспекты оценки стоимости объекта (EVE), представленные по мнению известных исследователей и с точки зрения стандартов оценки. В результате отметим, что критериальная схема оценок была дополнена критерием «по виду деятельности хозяйствующего субъекта». Мы описываем методы оценки, чтобы определить наиболее приемлемый и эффективный метод для этого важного для компании процесса. Что касается практического аспекта исследования, мы сосредоточились на методе сравнения при рыночной оценке предприятия, чтобы установить статистические показатели, состоящие в вычислении медианы и среднего арифметического. На основе расчетов, проведенных в практической части, мы установили, что экономический субъект может изменять собственную стоимость, в частности, делая свои ценности прибыльными. $B$ процессе оценки стоимости предприятия функция принятия решений возлагается на оценщика, в частности, в отношении выбранных и применяемых методов, путем соблюдения профессиональных стандартов оценки и действующих нормативных актов, поскольку справедливая оценка стоимости предприятия ведит к безопасному и гарантированному будущему.

Ключевые слова: субъект, стоимость, методы оценки, стандарты оценки, оценщик, оценка, медиана, среднее арифметическое.

The value is estimated most accurately by comparison.

\section{INTRODUCTION}

Estimating the value of the entity is an activity that becomes increasingly important, because the purpose of all economic operators is to carry out a profitable business. The assessment of the economic entity aims to provide a value of the economic entity, in this context the estimate of the value of an enterprise is intensified because its success ultimately depends on the level and how to remedy the value increase, also through management that focuses on the value of the entity. We argue that increasing the value of an entity contributes to a better reputation, which strengthens its safe positioning on the market, but also its stability. "The enterprise is itself a changing entity, obliged to continuously improve and adapt its level, structure and quality of transformations on input elements to meet the needs of the market, personnel, administration and to win itself in terms of profit, image, market share, extension capacity, resistance to competition, etc."(Deliu et al., 2011, 81-87).

We mention that the evaluation represents the process of estimating the value of goods of different types: tangible or intangible, movable or immobilized, of business, business actors, we emphasize that it is also the most important step in determining the fair value of an economic entity. The evaluation work is carried out by an evaluator through a thorough analysis and the outcome of the evaluator's work is based and confirmed using the entity's evaluation methods, based on the actual purpose of the evaluation. Each evaluation method refers to a time model that contains information about how the entity is evolving. Due to the evaluation of the value of the business, managers can identify new possibilities for the development and expansion of the 
business, but also eliminate the weaknesses of the company's activity.

The economy is always developing, which is why the entity's valuation methods must comply with these changing aspects, which are determined by local and international market rules. Investigating the aspects of assessing the cost and the economic entity's price mechanisms at a given time are very essential in calculating its fair value.

At the same time, we consider the overall value of the economic entity in the light of new evaluation methods versus the traditional ones to be very difficult to establish. At the same time, we note that in the practice of evaluation there are no standard models that allow the choice of evaluation methods, as it depends on many factors that are specific to a concrete situation. However, the evaluation standards are valid by the evaluation standards.

The declared role of evaluation standards is mainly: to establish procedures that to allow value certification under conditions comparable to national (domestic) and international law, evaluation practice and accounting standards; to assist evaluators by defining the fundamental elements of evaluation, creating a precise and compatible basis in practical activity; and to ensure quality parameters for evaluation beneficiaries"(Țuțui, f.a.).

\section{LITERATURE REVIEW}

Since the valuation has the ability to monitor certain external actions related to the entity, such as the influence of fixed assets, changes in market value in respect of intangible assets and others, respectively, we may mention that the valuation may also identify changes that are not found and presented in the accounting reports in a real way that will helps identify the entity's actual value. The main institutions of governance systems actively support the assessment of the entity's value. Of course, the evaluation contributes to the improvement, but, nevertheless, it is not always analyzed in a critical way (The Evaluation Enterprise, f.a., 2020, 6).

A proposed objective for the achievement of this study is to deepen knowledge in the conceptual field in the process of estimating the e entity's value. To this end, we will then give a description of the scientific approach to assessing the value of the entity in the literature.

Most frequently, the valuation is carried out on financial markets and less on other markets in order to clarify the financial situation, to establish the adaptation to the regulation s in force or the association of proprietary transactions. In support of this process, the International Assessment Standards (IES) are developed globally for the purpose of carrying out the evaluation tasks, by using the generally recognized concepts and principles. IES ensures transparency and consistency in evaluation practice. In this context, the International Assessment Standards Committee (IVSC) contributes to the formation to practical approaches to the activities and qualifications of professional assessors. At the same time, we consider it important to stress that in order to comply with international evaluation standards, the evaluation must be carried out in accordance with all the rules that are established by the IES, arising from the purpose and conditions set out in the evaluation process.

For the purpose of estimating the value of the entity, the completion of the entity's valuation process should be carried out on a regular and credible basis. This process begins by identifying by the evaluator the entity that should be evaluated and the basis of the evaluation and ends with reporting the conclusions to the client.

The evaluation has been defined by some researchers as a set of techniques, processes and methods by which the value of a good, group of goods, asset or enterprise is established, is a simple operation of weighing, measuring, etc., being a complex process of estimating the value (Deaconu, 2002).

The evaluation is also defined by other researchers "as the process of estimating a type of value (e.g. market value, insurance value, subjective value, liquidation value, etc.) of a particular identified property at a certain date", and the estimation process involves both elements of "assessment science" and elements of the evaluator's ability, synthesized by the word "assessment art" (Proiect Procesul de Evaluare a Intreprinderii - Sinteza Diagnosticelor, f.a.).

The Romanian researcher Ion Ionita states that "the evaluation of the organization involves not only establishing the value of some properties or assets of its heritage, but also determining its 
ability to generate cash flows that the owner of the organization will benefit from, since it is an asset which in turn generates goods"(Ioniță, 2007).

If we define the valuation process from the accounting point of view, it "consists in the quantification and expression in monetary units of the size of the assets (assets, liabilities, expenses and revenues) and of the economic and financial operations with changes in the assets mass" (Oprea and Ristea, 2000).

Thus, by generalizing the above mentioned, we define the estimate of the entity's value as the process of determining two types of values (market or non-market) of the business, with the main purpose of profit-making, and the performance, determined by the evaluator within a determined period, allows the development in perspective through a more efficient organization of revenues, through multilateral market research and, inevitably, competition. In the opinion of the authors, the purpose of an evaluation is, firstly, to establish the value of the entity by applying the appropriate valuation methods in accordance with the specific features of that entity, in particular by applying the processes and methods, which are maximum accepted by successful evaluators and, secondly, in continuously monitoring and managing the value creation process in order to maximize the market value. The essential role in the process of actual estimation of the value of the entity shall be assigned to the assessor with professional skills, theoretical and practical knowledge.

If we refer to the national level, in the Legislation of the Republic of Moldova, "assessment is a process of determining the value of the evaluation object at a determined date, taking into account the physical, economical, social and other factors that influence the value".

According to the Guide on Participatory Monitoring and Evaluation of Social Services, referring to civil society organizations, "the evaluation is an activity of in-depth analysis of interventions in the light of the results achieved, the impact, the satisfaction of needs, to which the public policy, the project, the service, the planned activity have set out to respond. The evaluation refers to the analysis of the extent to which the objectives have been achieved, the exposure of assessments of how effective and efficient the process was, how relevant the activities were, how sustainable the results were achieved" [SOROS, 2019].

Some bibliographical sources related to the investigated topic reveal that these researches are focused on the description of the conceptual foundations of the evaluation activity, on the types of values that represent the basis of the evaluation activity, on the description of the evaluation methods, the place, the role of the evaluation of entities and their regulation in the activity of commercial banks, etc.(Băncilă, 2007).

The financial aspect of the entity's valuation is quite complex, as it represents a synthesis area, where various methods of investment selection, financial forecasting and financial decision-making are used at the same time. In economic practice, the assessment is analyzed as an activity of estimating the value of economic goods, property rights over them, technologies and advantages relating to the assets of economic units and the future profitability created by them. It is worth mentioning that the evaluation process, according to the analyzed bibliography, takes place in stages and constitutes a set of well-defined operations that initiate with the definition of the evaluation mission, follows the collection and analysis of information by applying the methods appropriate to this process, so that finally a special act - the evaluation report(Băncilă et al., 2014).

Further to the study, another researcher in the field proposed a new paradigm within the process of evaluating the heritage of the republic, being argued due to the delimitation of the currents of the theory of evaluation to the contemporary stage. The author argues the correctness of the evaluation theory based on the value based on low entropy, the appropriateness of developing the method of estimating the actual value of the goods according to the entropic and classified value. This paradigm imposes ways of evaluating public assets in emerging economies as a result of highlighting the particularities of the public heritage assessment and the elaboration of the methodology for the evaluation of public assets in the Republic of Moldova (Albu, 2012).

The assessment importance of the value of economic entities in the Republic of Moldova, was initially highlighted during the period of privatization and restructuring of enterprises, which was considered as an important indicator in the development of the real estate market and the market for evaluation services, respectively of the evaluation activity. At the stage of privatization of 
enterprises, the primary concern focused on the correct calculation of the value of assets for privatization, including the approval, modification and completion of normative acts in the field of privatization by the Government of the Republic of Moldova, included in Judgment No. 561 of 10.08.1995. I will mention that for the mass privatization of enterprises the method of republican auctions with subscription to shares was applied, with the participation of 3.1 million citizens or 89 percent of the holders of property vouchers. Over the course of a year and a half, 15 Republican auctions with stock underwriting, 94 auctions and 11 public contests were held. As a result, 2235 enterprises (in whole or in part) and 191 thousand apartments were privatized in exchange for property vouchers. Subsequently, the evaluation activity was established by the Law on evaluation activity, No. 989-XV of 18.04.2002, in which we find the definition of the general concept of evaluation, with the exception of the definition of value.

The most important issues put forward for debate and resolution were: the organization of the framework of the evaluation work, the review of the legal, methodological and practical aspects of the evaluation work. In this context, in 2003, the Provisional Regulation on the evaluation of immovable property, drawn up under the 2002 Law, without including methods and techniques for the evaluation of enterprises as property complexes, was approved, and "The State Agency for Land relations and Cadaster had to draw up appropriate measures for the application of the provisions of the nominated Regulation in order to estimate the market value of real estate by valuation undertakings, regardless of the type of ownership and the organizational-legal form".

Simultaneously, in the context of globalization, state capacity to shape the national economic policy, including the using of attracted foreigner funds and resources, operational efficiency of natural, resources, intellectual capacity growth, location and internalization advantages, connections to world markets can increase (Plaskova et al., 2018), (Spivakovskyy et al., 2019), (Prodanova et al., 2019).

Currently, in the Republic of Moldova the Law on Evaluation Activity No. 989-XV of 18.04.2002 is valid, published on 16-07-2002 in Official Monitor No. 102 art. 773, version in force from 17.08.18 on the basis of amendments by LP173 from 26.07.18, M0309-320/17.08.18 art.492. The central public administration body is the Agency for Land and Cadaster Relations of the Republic of Moldova, which carries out the state policy in the field of land relations, cadaster, geodesy, cartography, geoinformatics, subordinated by the Government of the Republic of Moldova according to Government Decision No. 383 of 12 May 2010, with subsequent amendments and additions.

On 21 April 2018, representatives of the Institute of Standardization of Moldova (ISM), ministries, public associations of assessors, academia and the private sector participated in the first meeting of the Working Group on the elaboration of Moldovan evaluation standards that took place in the premises of the Agency for Land and Cadaster Relations of the Republic of Moldova. The meeting participants discussed the subject related to the takeover and publication of international and European Standards for the Evaluation of Goods, developed by the International Assessment Standards Council (IVSC) and the European Group of Evaluators' Associations (TEGoVA). At the same time, in order to ensure an effective collaboration between ISM and ARFC, the Technical Committee for Standardization CT 64 "Evaluation of Assets" was established, in order to streamline the process of taking over, adopting and implementing in the Republic of Moldova the European and International Standards for the Evaluation of Real Estate (Elaborarea standardelor moldoveneti, f.a., 2018).

It is known that the evaluation activity is regulated by the Evaluation Standards. The European Assessment Standards state: "evaluation is the process of estimating value", and in the International Accounting Standards the valuation is defined as a process by which the values at which the structures of the financial statements will be recognized in the balance sheet and in the profit and loss account"[IAS 2000:64]. The International Assessment Standards state that: "the evaluation is intended to express and certify the value, correctly and unambiguously, in accordance with national and supranational legislation, in accordance with the valuation standards and accounting standards between valuations in order to build indices that reflect financial performance and consistency" (Champness, 1997). 
It should be noted that the International Assessment Standards Committee (IVSC), since 1981, has been developing international evaluation standards (IVSs). Since 1997, the European Association of Evaluators (TEGoVA), which develops the European Assessment Standards (EVS), has also been part of this activity. Those standards include: the economic, financial and cultural peculiarities of several countries of the European Community. In the same vein, we recall that the work of assessor was first practiced in England in 1868, through the creation of the Organization of Real Estate Evaluators, currently - the Royal Institution of Chartered. The main objective of this organization is to remedy the evaluation process, but also to promote the evaluator profession. The university discipline of evaluator is taught in the Institute of Evaluation, formerly the American Institute of Real Estate Evaluators of North America, since 1932(Bîrcă, 2020).

In this context, we note that the profession of evaluator in Romania emerged in 1992, with the establishment of the National Association of Evaluators in the country. The evaluation activity was regulated by the National Assessment Standards (EVS) until 2000, after which they were replaced by International Evaluation Standards (IVSs), and the National Association of Authorized Evaluators of Romania [ANEVAR, 2020] was affiliated with the IVSC. ANEVAR is the Institute of Research in the field of evaluation, established in 1995 under the name IROVAL. The practical evaluation work is carried out on the basis of the ANEVAR Evaluation Standards and the Code of Ethics of the evaluator profession, developed by ANEVAR. The evaluation work is in line with international practice in the field of evaluation, these standards being designed on the basis of international standards, to which have been added elements related to the regulation of evaluation practice in Romania, through the Methodological Guides. The set of standards shall contain the practical work of evaluating undertakings and shall include:

$\checkmark$ General standards: SEV 100 General Framework (IVS General Framework), SEV 101 Evaluation Terms of Reference (IVS 101), SEV 102 Implementation (IVS 102), SEV 103 Reporting (IVS 103).

$\checkmark$ Asset Standards: Enterprises, Trade Fund and Other Intangible Assets, SEV 200 Enterprises and Business Participations (IVS 200), SEV 210 Intangible Assets (IVS 210), GEV 600 Enterprise Assessment.

Thus, as of 31 May 2012, the Evaluation Standards have become mandatory for evaluation work following the entry into force of Ordinance No 24/2011 on certain measures in the field of asset valuation [OG 24/2011]. The evaluator shall take all measures to ensure that all sources of information that have been used are adequate and credible for carrying out the assessment. The standard of assessment PRACTICE GN 6 "Enterprise assessment" states that "the evaluator will follow the reasonable steps to verify the accuracy and credibility of the sources of information and whether they are consistent with the practices in the markets and places where the evaluation is carried out" (Standarde / ANEVAR, f.a.).

The most frequent, the following economic concepts are applied in the company evaluation activity: ownership, value, ability to generate profit, which means that the value of the enterprise is based on its ability to profit from activities for the owner. As a result, that value is based on the company's profits, which will be obtained if the business complies with the principle of continuity. Only if the present value of the profits, which would result if the whole undertaking were liquidated (liquidation value), exceeds the value of the business as an undertaking in operation, would the liquidation value be presented as the value of the undertaking. The calculation of the value of the enterprise as the value of the discounted earnings can be created on the capitalization methodology or on the updated monetary flow techniques (Tîrlea, 2012, p.15). The value of the entity is determined by internal and external factors (Figure 1). 


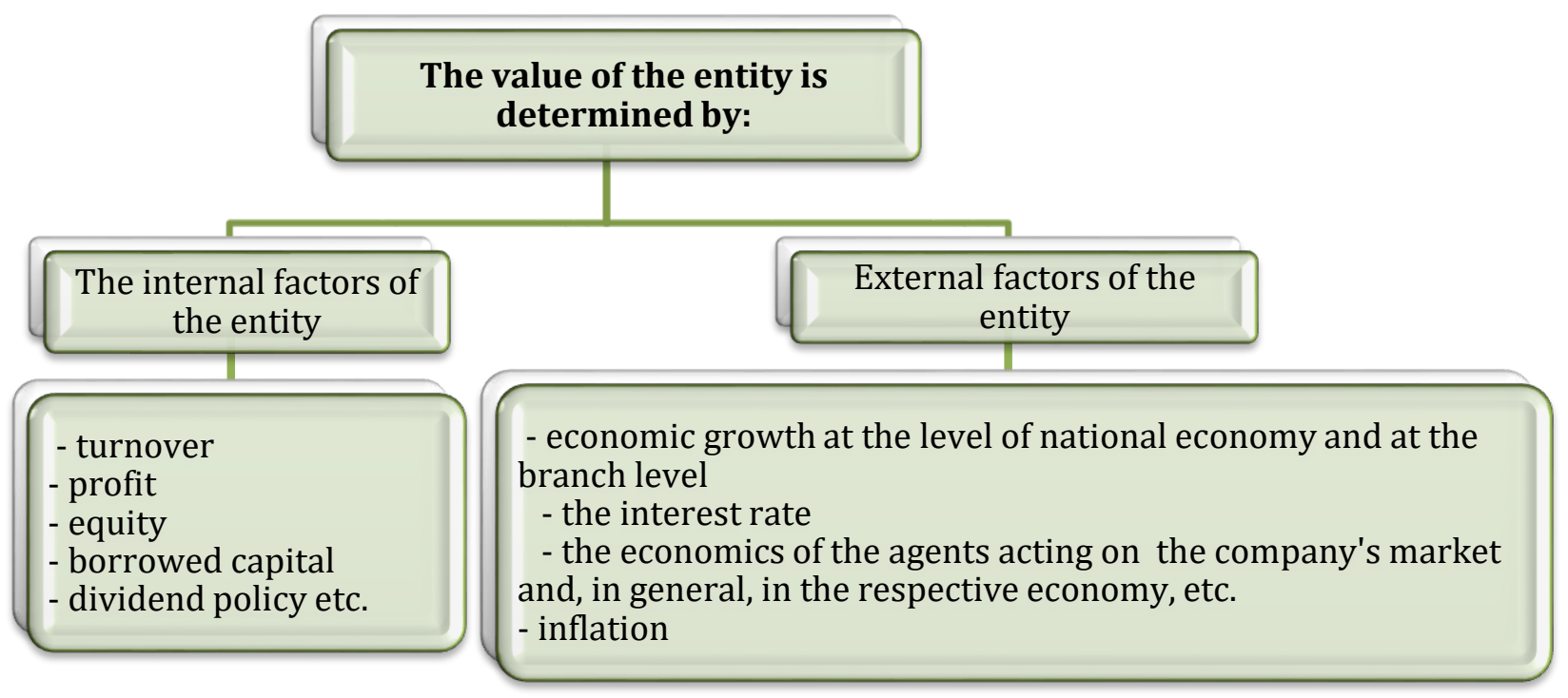

Figure 1. Factors determining the value of the entity

Source: Developed by authors.

In the opinion of the authors, it is necessary to evaluate the entity for several reasons: the existence of factors having a stable impact on the value of the entity, for example: influences related to the existence of free prices and changes in the exchange ratio of the national currency; the internal management of each undertaking, i.e. depreciation policies and accounting policies; depreciation of fixed capital; management accounting. For a qualitative assessment, all price changes in the market must be identified, it is necessary to find and measure the impact of these changes on the value of the goods in each undertaking, but also of each undertaking as a whole by using professional evaluation procedures.

In accordance with paragraph 22 of GEV 600, the assessment of the entity's economic situation shall be carried out by analyzing the financial statements in monetary and percentage terms, using specific financial indicators (Figure 2).

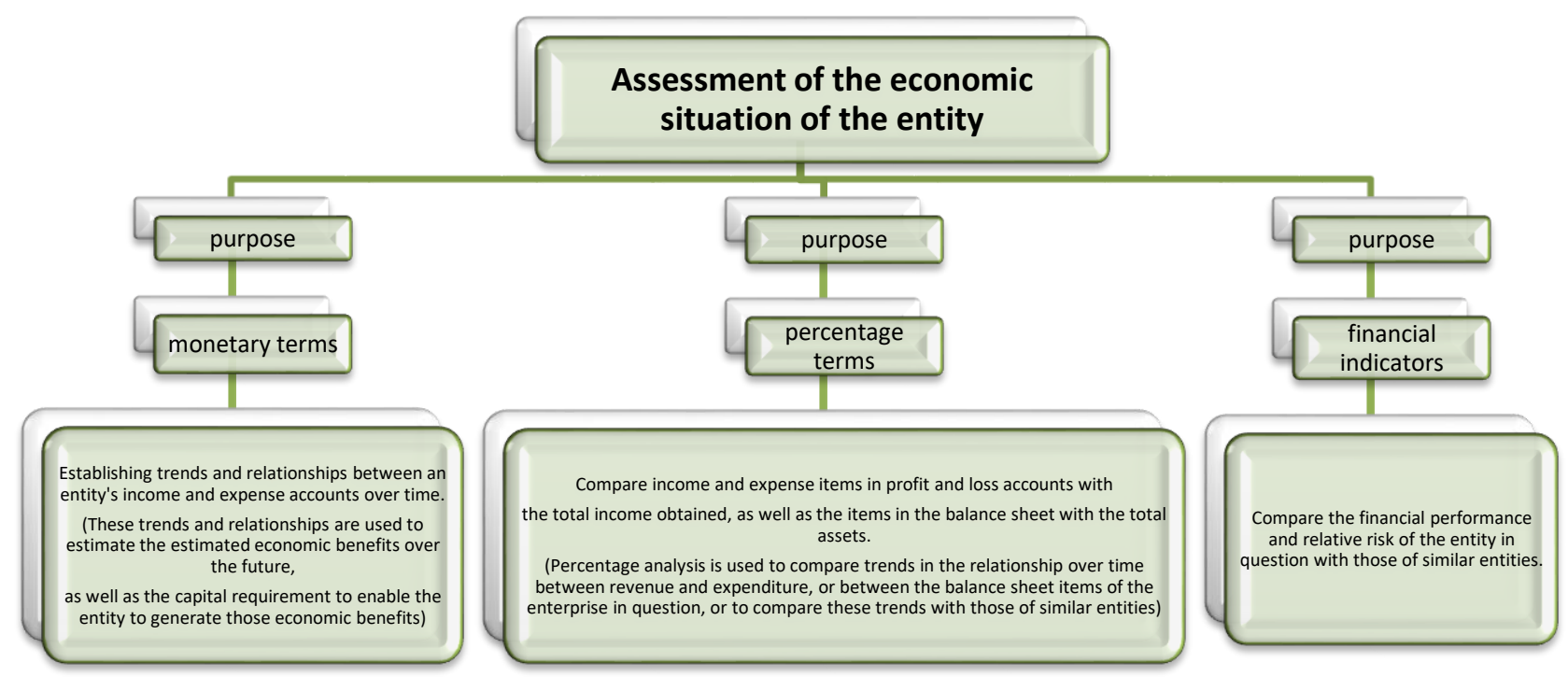

Figure 2. Assessment of the entity's economic situation using specific financial indicators (in monetary and percentage terms)

Source: Developed by authors based on GEV 600. 


\section{DATA SOURCES AND USED METHODS}

The study consists of theoretical-methodological research on the approach of the value of economic entities, including: analysis of literature, study of International Assessment Standards, European Assessment Standards and National Assessment Standards approved by the Government of the Republic of Moldova, which constitute normative acts applied by evaluators. In the practical part, we focused on the method of comparison in the market valuation of the enterprise.

\section{RESULTS OF OWN RESEARCH AND DISCUSSIONS}

As a result of the research of the specialized literature, especially regarding the specifics of the classification of the economic evaluation procedure, we found that the opinions regarding the classification of the evaluation of the economic value of the entity are different. Thus, in the view of Dumitrescu D. et al., "Evaluations can be classified according to 5 criteria: 1 . according to the goal pursued; 2 . by the method used; 3 . from the point of view of the evaluated object; 4 . according to the beneficiary of the evaluation; 5 . according to the position of the evaluator (Dragotă et al., f.a. 2002, p. 26). Instead, researcher Tirlea M.R. reports that the evaluation of the value of an enterprise for different purposes allows the classification of evaluations according to 6 criteria: 1 . from the point of view of the object of evaluation; 2 . from the point of view of the purpose of the evaluation; 3 . from the point of view of the beneficiary of the evaluation; 4 . depending on the position of the evaluator towards the enterprise; 5 . from the point of view of the evaluation method used; 6. in terms of value used (Ţîrlea, 2012b, p. 28).

Thus, we graphically present the criteria for classifying evaluations in Figure 3.

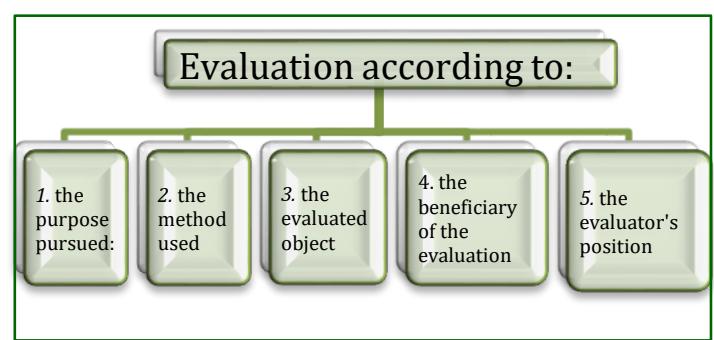

$a$

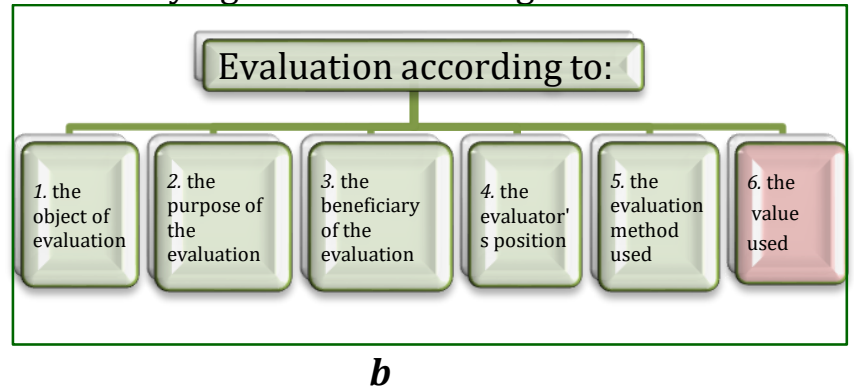

b

Source: Developed by authors based on (Dragotă et al., 2002, p. 26).

According to the information presented in Figure 3, we note that the result of the classification of evaluations highlights a criterion that distinguishes the position of the two researchers, this is the classification of the evaluations in terms of the value used: valuations based on market value, which we appreciate as a welcome complement to more real estimation of the value of the entity.

According to the authors, this supplement is considered to be criteria, however, we consider that the criteria scheme of evaluations can be supplemented by the following criterion: by type of activity of the economic entity. According to this criterion, valuations are classified in valuations for publicly traded economic entities and valuations for non-listed entities (Figure 4).

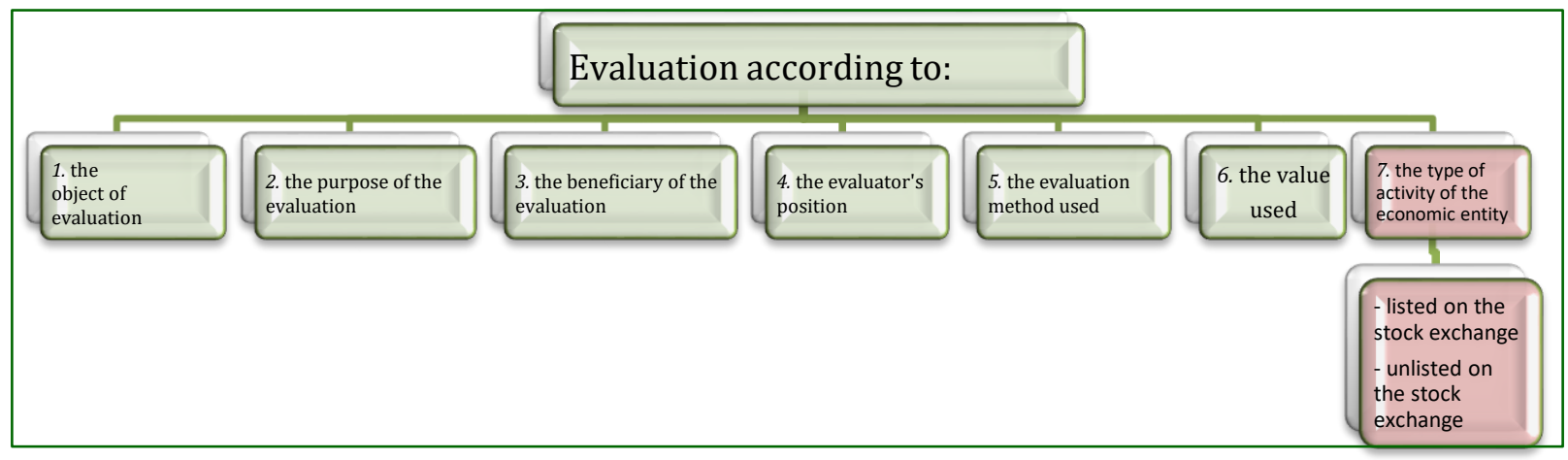

Figure 4. Criteria for classification of completed assessments

Source: Developed by authors. 
One of the objectives of the study is to choose the most relevant method for evaluating the enterprise on a specific case, taking into account the three approaches used to estimate the value of enterprises.

In the Republic of Moldova, in practice, three main approaches are applied for estimating the value of enterprises - through income, through spending and market (comparative). The general picture of the evaluation process of enterprises in the Republic of Moldova can be presented by the following characteristics:

- in the evaluation of the entity it is important to know the specific adjustments applicable to the different valuation methods according to the given situation;

- from the point of view of the financial information provided by the capital market, there is no sufficient correlation between traditional performance indicators and average market rates

- the valuation of the undertaking based on three value approaches (active or costs, income and comparison) is promoted;

- the mechanical application of comparison evaluation is a challenge for the current economic situation, which can lead to errors;

- a particular importance must be given to the professionalism of the assessor in the application of the evaluation methods; when the method is selected, the evaluator must take into account the context of his mission, determine the relevance of the methods according to the field of evaluation, quality, credibility and relevance of the available information, the appropriated objective of the evaluation.

However, it should be noted that the direct application of classic methods in the Republic of Moldova is difficult due to different objective reasons as: the insufficient development of the domestic securities market; limited access to information; the non-interference of the intervention has a large number of adjustments due to the lack of transparency in the accounting; long-term planning, in actual conditions, due to difficulties in the approach application of the revenue method on evaluation; the accounting assessment of the assets is significantly reduced compared to the market assessment.

In this context, we report that all methods of approaching the market for business valuation are based on the principle of competition, according to which, in a free market, the interaction between supply and demand will bring the price of business assets to a certain equilibrium.

Turning to the Market Approach which includes the comparison method, I note that this approach is aimed at setting market limits by analyzing the prices normally paid to companies that are competing with the company that has been assessed. Prices are analyzed using appropriate criteria. The direct comparison method sometimes requires adjustments. The mechanism for using this method involves the use of company accounting data, in addition to market and price indicators. This method uses two types of values: market value and liquidation value.

In the context of this study, I would point out that a particular contribution to the market valuation of the undertaking is provided by the comparison method. This refers to the analysis and comparison of the business that is evaluated with competitive companies operating in the market. Information for this method is obtained from open stock markets, previous transactions with business assets and the absorption market. The comparative method is based on comparing the value of the company with similar undertakings on the market according to their ownership. In practice, it is difficult to obtain accurate data, as market information about competitors may be inaccessible or distorted. In addition, competition obliges entrepreneurs to act unconventionally, which in turn shapes the specifics of each business. The comparison in this case becomes ineffective.

This approach to business valuation is very similar to the comparable sales method used in the real estate valuation. The market price of the shares of companies in the same line of business that are actively bought and sold on the open and free market may be an indicator of the market value of transactions involving a sufficient number of shares. The main task of the evaluator is to select a similar undertaking for the comparative study.

The essence of the comparative approach is that the assessed undertaking and the rights transferred to it are compared with rights and similar undertakings that have been sold on the market recently. During the comparison process, sales data is used to deduce the market value of the company being evaluated. 
An important aspect when applying the approach studied is the requirement for the availability of reliable and high-quality information required for evaluation. If the evaluator can find data on several similar sales that form a sufficiently representative sample, then he will have more confidence in the reliability of the original information. Similar undertakings should be comparable in terms of the following indicators, which are basic benchmarks for comparison:

- the business must be of the same type;

- the size of the business (sales) must be comparable;

- the form of ownership (rights to the undertaking) must be similar (Smirnickij and Čirkin, 2013)

Depending on the purpose of the evaluation and the specific context of the evaluation, the comparative approach involves the use of three main methods:

- the capital market method;

- market transaction method;

- the method of industry coefficients.

The capital market method (or peer company method) is based on the use of prices generated by the open capital market. In this method, the basis for comparison is the price of a share of companies or public enterprises. In the classical assessment, this method is used to assess a minority holding.

In this context, we will make a concrete point with reference to the methods of market evaluation, implemented in CIS countries, which in most cases correspond to the globally recognized approaches and methods. At the same time, a specific feature of the assessment in these countries is its excessive regulation. Being reflected in national normative acts, the evaluation methods need to be applied unconditionally and involve the application of established algorithms (Buzu, 2011, p. 402). However, in recent years, there has been a wider trend of application, including in the Republic of Moldova, of the International and European Assessment Standards.

The market transaction method is also called the sales method, it focuses on the purchase price of an undertaking as a whole or on a control stake.

The industry coefficient method (industrial multiplier method, price ratio method) shall be used if the evaluator considers that comparable sales data are insufficient and their reliability questionable. In this case, due to insufficient statistical or public sales data, different industrial and regional relationships may be used. In the practice of developed countries, sectoral coefficients are calculated on the basis of long-term statistical observations of the sales prices of companies in certain sectors and their most important financial and production characteristics (Shannon, 1988).

As a result of the study, the following advantages of the comparative approach to business evaluation can be distinguished:

- the use of direct market benchmarks, the minimum number of adjustments, which fully reflect the market view of the undertaking's 'value';

- allows an express rapid assessment of the value of the undertaking;

- can be used to validate cost reference values derived from other approaches.

At the same time, we will also report some of the identified disadvantages of the given approach:

- for proper use, careful selection of appropriate analogue objects and collection of a large amount of information about them is necessary, which is far from always feasible, especially in the context of a small and non-transparent market in the Republic of Moldova;

- depends, inevitably, on the efficiency and current state of the market.

At the same time, according to Romania's experience, we note that in order to carry out the evaluation of the SEV-2018 International Standard presents three types of approaches embodied in: 1. market approach; 2 income-based approach; 3 . the asset-based approach.

I. The market approach is based on the comparison of the assessed entity with other similar undertakings. Comparison of the company valued with other companies through this type of approach involves:

$\checkmark$ comparison with entities that have been traded on the free market;

$\checkmark$ comparison with similar entities with holdings in undertakings that have been traded on the free market;

$\checkmark$ comparison with similar entities, with shares that have been traded on the free market. 
In order to compare the evaluated entity with similar ones, data and information will be used to highlight the common comparison characteristics. It is important that this data and information are able to provide all the characteristics necessary to carry out comparability.

Comparative coordinates that ensure comparability refer to legal conditions, ownership, legal restrictions, location, physical characteristics, available utilities, financing conditions, conditions of sale, market conditions, zoning and best use.

Therefore, the market approach in the valuation of the undertaking, in accordance with C15, IVS 200 , consists of comparing the subject undertaking with:

$\checkmark$ other similar undertakings with participation in similar undertakings traded on the market;

$\checkmark$ relevant transactions with the participations of the subject enterprise;

$\checkmark$ previous transactions.

Capital markets provide sources of information on the qualitative and quantitative characteristics of similar undertakings. The analysis of a quantitative but also qualitative nature, according to IVS 200, requires the evaluator to identify the representative characteristics of the subject undertaking which should be analyzed in comparison with those of the undertakings identified as similar which involve the analysis:

1. in the area of the geographical area in which the undertakings concerned operate;

2. the level of profit;

3. the level of sales;

4. the structure of sales;

5. the level of assets;

6. asset structure;

7. the level of profit margins;

8. growth forecasts; etc.

II. The income-based approach illustrates the entity's ability to generate revenue through techniques to update future benefits. The income approach involves updating income streams. Specifically, this method estimates the value of an entity based on the present value of future benefits. In practice, two methods are used: (i) discounted net cash flow aimed at updating net cash flows for the forecast period with a discount rate and (ii) the dividend method. The income approach is a method of yield that illustrates the entity's ability to generate revenue through updating techniques. The purpose of applying this method is to obtain the value of an entity by calculating the present value of the anticipated benefits based on the revenue and cost structure presented in the balance sheet that reflects the economic and financial situation of the assessed entity resulting in the entity's ability to generate cash flows over a period of time.

III. The choice of the asset valuation of the assessed entity involves estimating the value using methods based on the market value of the assets from which the liabilities are deducted. The balance sheet at the time of valuation, the company's assets and liabilities are those that play the basic role in this type of valuation. The asset approach usually applies to early-stage or newly established undertakings whose profits or cash flows cannot be credibly determined.

Therefore, by generalizing, we point out that for the purpose of assessing the undertaking, the comparison involves:

$\checkmark$ all calculations made by the evaluator are carried out in a similar way, both for the undertaking under the subject matter and for similar undertakings which have been studied for research and evaluation;

$\checkmark$ the price data are valid at the time of the assessment;

$\checkmark$ data collected on financial indicators of similar undertakings may be historical information on financial indicators and the nature of the information collected;

$\checkmark$ statistical indicators of a medium, median, harmonic mean nature must be motivated by the evaluator;

$\checkmark$ aspects of the adjustment of financial indicators must be adequately substantiated;

$\checkmark$ The multipliers used require the evaluator to argue the option for them;

$\checkmark$ the market information of similar undertakings must be relevant to the assessment of the undertaking subject;

$\checkmark$ adjustments to market information should be explained in the evaluation report; 
$\checkmark$ previous transactions may be considered comparable only if the adjustments can be substantiated;

$\checkmark$ application of premiums or discounts is possible to reflect different levels of control, liquidity/solvency, etc.

For practical exemplification, ten entities similar to the evaluated subject entity were selected in order to determine the statistical indicators consisting of the calculation of the median and the arithmetic mean.

At the time of assessment, the indicators related to the subject entity are presented as follows: price per share 90 lei, net accounting asset 190, net accounting asset per share 2 , net accounting asset price 1.05 and financial return 8\%, according to the graphic representation below.

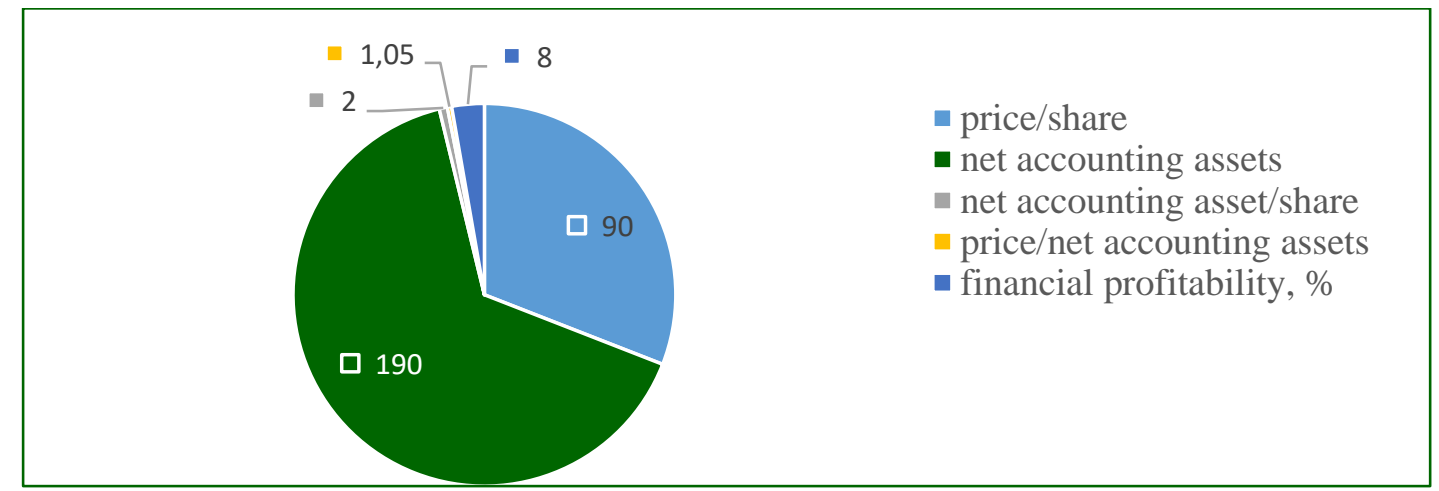

Figure 5. The Situation of the Entity (S) evaluated

Source: Developed by authors.

According to the data in Figure 5, we find that in order to make an estimate of the market value of the subject enterprise we assessed as net accounting price/asset and the relationship between profitability and net accounting price/asset proved to be relevant. Financial profitability is dependent on the price per share and the book value of the share.

The shares constitute shares of the subscribed and paid-up share capital. The market value of the shares is determined as the ratio between the market value of the equity and the number of shares issued.

The study took into account ten economic entities in the market: A,B,C,D,E,F,G,H,I,J. These economic entities are comparable to the subject entity. The comparison criteria are translated into: price per share, net accounting asset, net accounting asset per share, net accounting asset price and financial return.

At the time of the evolution, the indicators related to comparable entities were provided to us by an active market, as presented according to table 1 and related graphical representation.

Table 1

Situation of entities similar to the entity assessed

\begin{tabular}{|c|c|c|c|c|c|c|}
\hline $\begin{array}{l}\text { No. } \\
\text { Crt. }\end{array}$ & $\begin{array}{l}\text { The evaluated } \\
\text { entity }\end{array}$ & $\begin{array}{l}\text { Price/ } \\
\text { Action }\end{array}$ & $\begin{array}{c}\text { Net } \\
\text { accounting } \\
\text { assets }\end{array}$ & $\begin{array}{l}\text { Net accounting } \\
\text { asset / share }\end{array}$ & $\begin{array}{l}\text { Price / Net } \\
\text { accounting } \\
\text { assets }\end{array}$ & $\begin{array}{c}\text { Financial } \\
\text { profitability } \\
(\%)\end{array}$ \\
\hline 0. & 1 & 2 & 3 & 4 & 5 & 6 \\
\hline 1. & $\mathrm{~A}$ & 90 & 190 & 2,00 & 1,55 & 7 \\
\hline 2. & $\mathrm{~B}$ & 80 & 165 & 2,06 & 1,24 & 10 \\
\hline 3. & $\mathrm{C}$ & 85 & 170 & 2,00 & 1,17 & 6 \\
\hline 4. & $\mathrm{D}$ & 87 & 165 & 1,89 & 1,14 & 8 \\
\hline 5. & And & 77 & 170 & 2,20 & 1,29 & 7 \\
\hline 6. & $\mathrm{~F}$ & 86 & 172 & 2,00 & 1,16 & 5 \\
\hline 7. & $\mathrm{G}$ & 71 & 152 & 2,14 & 1,4 & 4 \\
\hline 8. & $\mathrm{H}$ & 79 & 142 & 1,79 & 1,26 & 6 \\
\hline 9. & $\mathrm{I}$ & 91 & 198 & 2,17 & 1,09 & 10 \\
\hline 10. & $\mathrm{~J}$ & 74 & 160 & 2,16 & 1,35 & 10 \\
\hline 11. & Arithmetic mean & & & & 1,21 & 7,4 \\
\hline 12. & Median & & & & 1,20 & 7,36 \\
\hline
\end{tabular}

Source: Developed by authors. 
The calculations carried out led us:

$\checkmark$ at an arithmetic average for the net accounting asset price of 1.21 and the financial return is $7.4 \%$;

$\checkmark$ The median is 1.20 at the net accounting asset price and $7.36 \%$ at the financial return.

Comparable entities offer benchmarks for trading evaluated entities.

The comparison method reflects the best variant of the share price in the market.

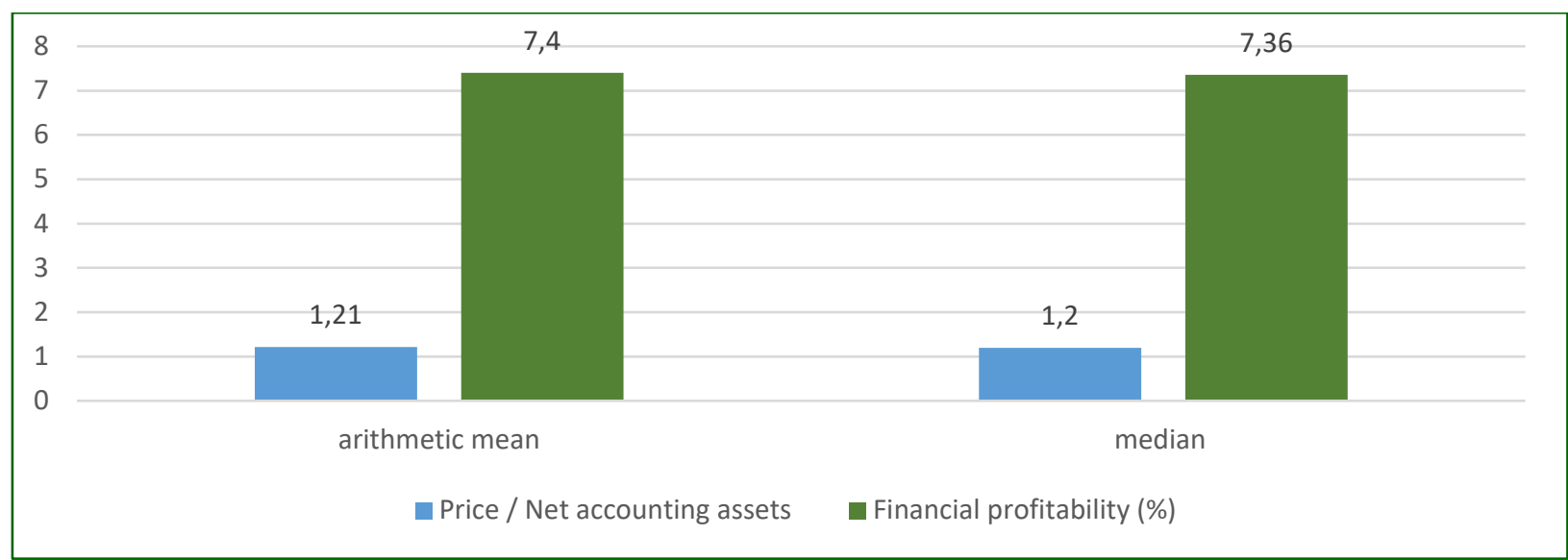

Figure 6. Arithmetic and median mean, calculated for entities similar to the entity assessed Source: Developed by authors.

Actions represent financial assets. As a result, they can be assessed on the basis of the three approaches used in the evaluation: the comparison method, the cost method and the future flow method.

The market value of a share is subject to the stock exchange rate.

In our case it is an active market. Shares are traded on a market that is thus efficient that the prices that have been registered for comparable transactions are credible.

The stock exchange rate determines, on the one hand, the market value of a share, and, on the other hand, demonstrates that the chosen method - the comparison method - is the most representative method of valuation.

\section{CONCLUSIONS}

Therefore, the value of the economic entity has become a benchmark for the development of all capacities in order to achieve short and long-term performance, to involve human resources, material means, etc.

By generalizing, we note that generally accepted methods for estimating the value of the entity are an indication of the success and efficient activity of both the enterprise and the assessor. Only because of the accurate and complex estimate of the value of the economic entity will we get a clear picture of both the successes and the gaps and failures to be removed. Effective management, following an evaluation report, will make every effort to achieve performing performance in economic activity by developing a capacity-based activity plan, but also taking into account the means of achieving performance.

We believe that in order to improve the evaluation activity it is necessary to multilaterally investigate the situation on the domestic and foreign market, in particular with regard to supply and demand through open access to the necessary information; strict observance of the regulatory acts in force on the assessment of the overall value of economic entities (VGEA), but also the adjustment and offering of remedial proposals as appropriate; direct state support and the creation of effective collaboration; and last but not least for the Republic of Moldova - the operation of the Land and Cadaster Relations Agency with all representatives in the field of evaluation.

In the global economy, the government must realize, first and foremost, the interests of domestic business as the most active, creative and aggressive elements of society, strongly supporting and guiding its expansion, considering it as one of the key instruments of national economic development and welfare. Inside their own society, government must support the people with its desire for justice and for more equitable resources' distribution. Sustainable economic progress in a complex system of 
world economic relations requires from the modern government to develop a set of measures, aimed at consolidating the domestic business. The businesses ability to form the transnational constructs of inputs and finished products distribution, is segmenting the national economy, by creating within the macroeconomic system the complex of autonomous 'strategic business zones', which are a weakly regulated by government due to the networking effects. As the condition of business consolidation, competitiveness of domestic production improving has "to become a new concept of market-based government functions, of public management, which infrastructure is, first and foremost, egovernment" (Ushakov et al., 2019, p. 2566-2573).

In order to make an estimate of the market value of the subject entity, the G/L Net Price/Asset ratio and the relationship between profitability and G/L Net Price/Asset are assessed as relevant. Financial profitability is dependent on the price per share and the book value of the share.

Thus, based on the study carried out, we will highlight the most important results obtained:

1. As a result, on the basis of the calculations made in the practical part, it was found that an economic entity can change its own value by the way its values are profitable (Table 1).

2. The difference between the classifications of evaluations in the literature was identified, it was found that the criterion distinguishing the position of the two researches is the classification of valuations in terms of value used, valuations based on market value and valuations based on values different from market value (Figure 3).

3. The criterion scheme of the evaluations was completed with the following criterion: "by type of activity of the economic entity: listed on the stock exchange and unlisted on the stock exchange" (Figure 3).

4. For the practical aspect of the investigation, we focused on the method of comparison in the market valuation of the entity, establishing the statistical indicators that consisted in the calculation of the median and the arithmetic mean (Figure 6).

In conclusion, it is noted that in the evaluation process of the entity a decision-making function falls to the selected methods, applied skillfully and skillfully by the evaluator in the evaluation process, i.e. it is a matter of the level of competence, theoretical knowledge and skills to apply them in practice, but not least to its professionalism. The determining factors of the value of the economic entity demonstrate that current policies must be focused on improving the environment both economically and socially.

\section{REFERENCES}

1. Albu, S. (2012). Evaluarea şi gestiunea eficientă a patrimoniului public în Republica Moldova [Teza de doctor habilitat în economie]. Universitatea Tehnică a Moldovei.

2. Băncilă, N. (2007). Teoria și practica de evaluare a unităților economice în baza cerințelor actuale bancare [Teza de doctor habilitat în economie]. Academia de Studii Economice a Moldovei.

3. Băncilă, N., Ganea, V., \& Mărgineanu, A. (2014). Reglementarea activității de evaluare în băncile comerciale. Analele Științifice ale Academiei de Studii Economice din Moldova, 1, 180-185.

4. Bîrcă, I. (2020). Evoluția conceptelor teoretice privind entitatea economică și estimarea valorii globale a eiprin prisma dezvoltării durabile. Univers strategic, 2(24), 128-145.

5. Buzu, 0. (2011). Priorităţile de evaluare a bunurilor imobile în ţările CSI. http://81.180.74.21:8080/xmlui/handle/5014/3916

6. Champness, P. (1997). Approved european property valuation standard. Estates Gazette.

7. Deaconu, A. (2002). Evaluarea afacerilor. Intelcredo.

8. Deliu, A., Bîrcă, I., \& Frăsineanu, P. (2011). Managementul schimbării şi schimbarea organizaţională-Premisă de sporire a performanţei întreprinderii. 2, 81-87.

9. Dragotă, V., Ciobanu, A., \& Dumitrescu, D. (f.a.). Evaluarea întreprinderilor (2-lea ed). București, Editura Economică. Preluat în 4 mai 2021, din http://www.edecon.ro/carte/133/evaluareaintreprinderilor-editia-a-ii-a_victor-dragota_anamaria-ciobanu_dalina-dumitrescu/

10. Elaborarea standardelor moldovenești. (f.a.). Preluat în 4 mai 2021, din https://standard.md/wp-

content/uploads/2020/11/RS_1_Elaborarea_standardelor_moldoveneti.pdf 
11. Ioniță, I. (2007). Evaluarea sistemelor tehnico-economice. București, Editura Economică.

12. Oprea, C., \& Ristea, M. (2000). Bazele contabilitatii.

13. Plaskova, N. S., Prodanova, N. A., Zatsarinnaya, E. I., Korshunova, L. N., \& Chumakova, N. V. (2018). Methodological Support of Organizations Implementing Innovative Activities Investment Attractiveness Estimation. Journal of Advanced Research in Law and Economics, 8(8), 2533. https://doi.org/10.14505//jarle.v8.8(30).25

14. Prodanova, N. A., Trofimova, L. B., Aleksandrovich, A., Erzinkyan, E. A., Savina, N. V., \& Nikolaevna, L. (2019). Methodology for Assessing Control in The Formation of Financial Statements of a Consolidated Business. International Journal of Recent Technology and Engineering, 8(1), 7.

15. Proiect Procesul de Evaluare a Intreprinderii-Sinteza Diagnosticelor. (f.a.). RegieLive. Preluat în 4 mai 2021, din https://biblioteca.regielive.ro/proiecte/finante/procesul-de-evaluare-aintreprinderii-sinteza-diagnosticelor-323088.html

16. Shannon, P. P. (1988). Valuing a Property Management Company. Institut of Real Estate Management,.

17. Smirnickij, G. B., \& Čirkin, A. N. (2013). Ocenka biznesa: Osnovy, instrumentarij, praktika. Киев.

18. Spivakovskyy, S., Spivakovska, T., Kanishchenko, O., \& El Alfy, S. (2019). Marketing Strategies of Companies in Internationalization Process. Journal of Advanced Research in Law and Economics, IX, 2155-2162. https://doi.org/10.14505//jarle.v9.6(36).30

19. Standarde / ANEVAR. (f.a.). Preluat în 4 mai 2021, din http://site2.anevar.ro/pagini/standarde

20. The Evaluation Enterprise: A Critical View. (f.a.). Routledge \& CRC Press. Preluat în 4 mai 2021, din https://www.routledge.com/The-Evaluation-Enterprise-A-Critical-View/FuruboStame/p/book/9780367666064

21. Tîrlea, M. R. (2012a). Evaluarea întreprinderii. Risoprint.

22. Tîrlea, M. R. (2012b). Evaluarea întreprinderii. Risoprint.

23. Țuțui, D. (f.a.). Evaluarea Întreprinderii. https://www.academia.edu/24289305/EVALUAREA_\%C3\%8ENTREPRINDERIINNOTE_DE_CURS_I. Preluat în 4 mai 2021, din https://www.academia.edu/24289305/EVALUAREA_\%C3\%8ENTREPRINDERI_NOTE_DE_CURS_I

24. Ushakov, D. S., Sigidov, Y. I., Gribincea, A., Birca, I., \& Mashal, L. (2019). Governance Efficiency in Conditions of the World Economy Globalization and Digitalization. Journal of Advanced Research in Law and Economics, 10(8), 2566-2573-2566-2573. https://doi.org/10.14505/jarle.v10.8(46).35

\section{ARTICLE HISTORY}

Received 22 September 2020

Accepted 05 February 2021 